\title{
Analysis on Withdrawal of Rural Homestead in China under the Background of Urban and Rural Overall Development
}

\author{
--A Case Study of Centralized Residence
}

\author{
Sun Yanli \\ Weifang University \\ Weifang, Shandong Province, China
}

\author{
Xu Jiaqi \\ Guangzhou University of SCUT \\ Guangzhou, Guangdong Province, China
}

\begin{abstract}
Homestead withdrawal mechanism refers to a whole set of mechanisms with homestead withdrawal behavior as the core, including both homestead-centered withdrawal mechanism and compensation and guarantee mechanism to ensure the smooth realization of homestead withdrawal behavior. Its main function is to promote the smooth realization of homestead withdrawal behavior, improve land use efficiency, and promote the development of urban-rural integration. However, our country's homestead withdrawal mechanism is not perfect, and there are a series of problems, mainly including vague property rights of homestead, incomple te real rights and powers of the right to use homestead, lack of fixed-term paid use system of homestead, and defects in the conditions for the withdrawal of homestead. Through the analysis of the current pilot areas for withdrawal of residential land represented by concentrated residence, drawing on the successful experience, the existing problems are found out, and the withdrawal mechanism of rural residential land based on the coordinated development of urban and rural areas is analyzed.
\end{abstract}

Keywords-Urban and rural overall development, Chinese rural area, homestead withdrawal, centralized residence

\section{INTRODUCTION}

The current allocation and use of homestead in our country is based on a management system of social welfare under the era of planned economy. Members of village collective organizations that meet the conditions for applying for homestead can use one homestead in the village free of charge and indefinitely. However, China's current homestead management system, on the one hand, strictly restricts the market circulation of homestead, but on the other hand, lacks the withdrawal mechanism of homestead, which makes the current use of homestead widespread in large scale, overstandard area, multi-family residence, idle and inefficient use. With the acceleration of urbanization, both urban land and rural residential land will increase, and the double pressure of tight supply of construction land and protection of cultivated land will surge.

In recent years, under the opportunity of the implementation of policies and measures such as "linking the increase and decrease of urban and rural construction land" and "promoting the circulation of rural construction land", some areas have begun to explore the withdrawal of rural residential land. Typical "Land-bill Transaction" mode, "homestead for housing" mode, and "two-for-two" mode have emerged one after another. However, these models also have many problems, such as excessive administrative intervention by local governments, which results in dissatisfaction and resentment among farmers, lower compensation standards, and damage to property rights in rural areas. Among them, the core issue is the compensation and resettlement of homestead withdrawal. Therefore, in the process of homestead withdrawal, it is of great significance to establish a scientific and reasonable compensation and resettlement mechanism for the realization of rural homestead capitalization, improvement of land use efficiency, promotion of rural labor force transfer and agricultural industrialization development, acceleration of urbanization development, promotion of centralized residence of villagers, and promotion of urban-rural integration.

\section{THE IMPORTANT SIGNIFICANCE OF HOMESTEAD WITHDRAWAL IN THE OVERALL DEVELOPMENT OF URBAN AND RURAL AREAS}

Under the background that urbanization is actively and steadily advancing and land conservation and intensive needs to be improved, the efficient use of rural homestead has become an important platform to promote land conservation and intensive use. Under the background that urbanization is actively and steadily advancing and land conservation and intensive needs to be improved, the efficient use of rural homestead has become an important platform to promote land conservation and intensive use. It is an important starting point to improve the low efficiency of urban land use, an important lever to leverage the urbanization construction, and a po werful tool to promote the coordinated development of urban and rural areas.

\section{A. Innovation of homestead management system is an important way to solve the problems of agriculture, rural areas and farmers}

The solution to the problems of agriculture, rural areas and farmers is the core issue of the overall development of urban and rural areas. From the government's point of view, whether it is to guide and encourage farmers to settle down in cities for 
employment and entrepreneurship, to help them realize the transformation to the identity of urban residents and their production and life style, or to build a new socialist countryside and push forward the urbanization construction in rural areas, needs a steady stream of capital investment. However, if these investments are only maintained by the limited financial funds of the government or the funds for urban construction, the sustainability is insufficient. Only the market benefits brought about by the flow of land resources are the source of motivation for farmers to get rich from poverty and perfect rural construction. Therefore, one of the ways to effectively solve the problems of agriculture, rural areas and farmers is to reform and innovate the land management system, revitalize rural land resources and assets, make good use of land value-added income, and promote agricultural development, increase farmers' income and improve the rural environment.

\section{B. Economical and intensive land use in urban and rural areas is the fundamental requirement for overall development of urban and rural areas.}

With the advancement of industrialization and urbanization, the demand for land for economic and social development will further expand. If we continue to maintain the original extensive mode, we will definitely face a more serious contradiction between land supply and demand. Therefore, the overall development of urban and rural areas requires the strict protection of cultivated land as the premise, and the economical and intensive use of land as the core to effectively improve the efficiency of land use. Through the establishment and implementation of the rural homestead withdrawal mechanism, the current situation of extensive utilization of rural construction land can be effectively improved. At present, the economical and intensive land use lacks not only strict restrictive measures but also effective incentive mechanisms.

\section{Balancing urban and rural land markets is an important way to change the dual structure of urban and rural areas}

The most important issue facing the overall development of urban and rural areas is the reform of the current land management system and other basic systems. How to coordinate the differences between state and collective land ownership under the theme of the overall development of urban and rural areas, to promote the orderly flow of land resources in urban and rural areas, to ensure the urban and rural economy and the construction of urban and rural areas, and at the same time to enable farmers to obtain corresponding land benefits, is the key problem to solve the dual economic and social structure of urban and rural areas. Through the integration and allocation of all kinds of resources, especially land resources, the utilization efficiency will be improved and the common development of urban and rural areas will be realized.

\section{LOCAL REFORM EXPERIMENT ON HOMESTEAD WITHDRAWAL-CENTRALIZED RESIDENCE}

In short, centralized residence of farmers means that farmers living in villages are concentrated in communities. In recent years, in some counties and cities, such as Beijing,
Shanghai, Jiangsu, Zhejiang, Sichuan, Shandong, the local government has begun to explore how to lead farmers to live together. The earlier case of centralized residence of farmers was in Jiangsu province. Around 2001, there were some smallscale experiments of centralized residence of farmers in rich villages and towns in Suzhou, Wuxi and other places in southern Jiangsu. At that time, it was the high-speed development stage of industrialization in southern Jiangsu, and most of the young and middle-aged farmers entered the factory to work or do business. Therefore, the population in some villages reduced definitely, and turned into "empty villages". The local government began to try to merge some natural villages with small population into large villages with large population, or to build apartments for farmers.

In July 2003, Jiangsu Provincial Party Committee held the fifth session of the 10th national congress and proposed "two first" and decided to "build a moderately prosperous society in all respects by 2010; by 2020, basically realize modernization in general”. The southern Jiangsu region was entrusted with the important task of "pioneer". As the pace of urbanization in the region has greatly accelerated, industrial land is obviously tight. Under such circumstances, "rural three concentration" of Xinqiao town of Jiangyin city has become a typical example of intensive land use. To sum up, "rural three concentration" of Xinqiao town is to divide the total area of 19.3 square kilometer into three major functional areas, which includes 7 square kilometers of industrial park, 7 square kilometers of ecological agriculture area, and 5.3 square kilometers of residential and commercial areas. Three concentration means that all industries are concentrated in industry zone, farmers are concentrated in townships, and agricultural land is in scale management by local enterprises. The most important part is centralized residence of farmers. After centralized residence of farmers, the original village homestead and free land, etc. belong to the collective construction land, which can be directly used for industrial construction without approval. As a result, grass-roots spontaneous experiments were regarded as an advanced movement to "co-ordinate urban and rural planning" and were followed by all parts of the province for the time being. As a result, grass-roots spontaneous experiments were regarded as an advanced move to "urbanrural coordinated planning" and were followed by the whole province for a while.

Due to many areas are located partly in the outer suburbs or pure agricultural areas, rural homestead with little commercial value has also begun to be demolished and reclaimed under the leadership of the government, and largescale farmers have been promoted to live in concentrated communities. For example, Chengdu's "demolition and merging farmers' houses” test, Jiaxing's “Two-for-Two” test, Tianjin's "homestead for housing” mode, and Chongqing's "Land-bill Transaction" mode, and there are also many tests about centralized residence of farmers under the name of "new rural construction" and "overall urban-rural development", which includes that in Shandong, Zhucheng, Zibo, Linyi, Jining, Dezhou, Liaocheng, etc., the local government has implemented "change village to community" test and promoted centralized residence of farmers. Taking Zhucheng as an example, since 2007, as radius of 2 kilometers, the city's 
1249 villages have been planned to be built into 208 rural communities based on the principle of geographical proximity and similar customs, in which each community covers about 5 villages and 1500 households, leading farmers to live together in the center village. According to the reports, more than 20 provinces and autonomous regions have begun to promote centralized residence of farmers and the reclamation of homestead in pure agricultural areas with different forms and scales. In essence, these reform tests are the actions of local governments to obtain indicators of construction land by promoting the removal and reclamation of rural homestead and centralized residence of farmers. Although the reform measures in different regions are different, they are mainly reflected that in the level of compensation for demolition and relocation and the standard of centralized residence, some regions have more favorable conditions than other regions.

Undeniably, by activating rural collective construction land, on the one hand, urban areas can obtain more land use indicators; on the other hand, farmers can also share some of the land value-added benefits brought about by the urbanization process, and change their living condition and environment to improve living standard through the replacement of homestead, and village organization can use various forms to run industries and properties. In terms of improving rural infrastructure, living conditions and saving land, these measures are of reform and exploration significance for the unified planning of rural construction land, especially rural homestead, and the centralized resettlement of farmers. However, in the process of actual promotion, the local government often focuses too much on obtaining the index of construction land under the fact that the channels for people's appeal are not unblocked and the right to speak is ignored, especially under the background of land finance. Based on the consideration of cost-benefit and driven by the thinking pattern of the minority obeying the majority, the local government is keen on promoting large-scale demolition and construction, which infringes on the interests of farmers. Judging from the current practice of centralized residence of farmers in many parts of the country, as a result, farmers' homestead and farm housing often become small rural property housing with low economic value. In addition, farmers are also facing practical problems such as borrowing money to remove in apartments, raising the cost of living and lowering the convenience of production. Especially for the huge value-added benefits brought about by the change of land use, farmers are completely excluded and have no right to allocate, which objectively leads to the outflow of rural resources.

\section{ANALYSIS OF FACTORS ON AFFECTING THE IMPLEMENTATION OF CENTRALIZED RESIDENCE OF FARMERS}

\section{A. The main body of rural homestead ownership is in a virtual position and its power is violated}

Our country's laws clearly stipulate that rural homestead belongs to rural collective economic organization, and members of rural collective economic organization have the right to use homestead, but it is relatively vague in actual operation whether the collective economic organizations as the main body are "villages" or "groups". This kind of unclear property right leads to a lack of clear definition of "responsibility, right and benefit" of right to use rural homestead, which further leads to the difficulties of the owner to exercise the right to possess, use income and dispose according to law. As the main body of rural land ownership is in a virtual position, the village cadres assume some of the owner's rights, which results in the allocation of the right to use the homestead being seriously interfered by administrative forces. It not only results in unreasonable distribution of land resources, but also is not conducive to the harmonious and stable rural society.[1]

\section{B. Lacking adequate and effective public participation in centralized residence planning}

In the process of planning and implementing centralized residential areas, the major issues closely related to the interests of the masses, such as the location of concentrated residential areas, the layout of infrastructure, the design of apartments and landscaping, are involved. In order to get the support of the vast number of farmers, the centralized residence needs to ensure the farmers' all-round understanding and participation in the whole process of planning, so as to truly implement their right to know and participate. However, the fact is that farmers know little about the actual situation. The vast majority of farmers do not know where the index of collective construction land will land after they vacate the homestead. According to local policies, these indicators are partly converted to industrial land and partly to urban construction land, but the participation of farmers in the whole process is very weak as to how the value-added benefits are distributed. [2]

\section{Lacking effective market mechanism for rewards and punishments for withdrawal of homestead}

Homestead is the basic social security for farmers to settle down, and its nature is social welfare. For a long time, our country has implemented free and indefinite use of rural homestead, which objectively abets the trend of occupying more land and better land. The current land management laws, regulations and policies mainly manage the newly-added homestead, but still lack of systematic institutional norms for the main body, methods and benefit distribution of homestead withdrawal. At the same time, there is no powerful way to one household, multiple housing lands, one household, multiple housing lands and over-sized homestead in rural areas.

\section{ANALYSIS ON WITHDRAWAL MECHANISM OF RURAL HOMESTEAD BASED ON THE COORDINATED DEVELOPMENT OF URBAN AND RURAL AREAS}

As rational economic persons, in pursuit of maximizing personal interests, farmers generally do not voluntarily abandon the homestead which is legally applied, inherited, transferred or even illegally occupied. 


\section{A. Clarify property rights subject of homestead and its power}

Effective property rights system cannot only reduce transaction cost, but also maximize the incentive on rightholders to fully use their resources at full extent. First of all, return rights and entitle power -- make the ownership of the homestead clear to the villagers group, and let the members of villagers' group democratically decide the system of the homestead so as to ensure the rural collective members can enjoy the right to use the rural homestead on an equal basis. Secondly, clearly define the rights and power of the rural homestead, and rationally define the area standard and scope of the welfare homestead which meet the farmers' basic living requirements. The part above standard can be retracted by the collective economic organization after being approved by People's Government of the Town. Homestead idle or lost for over two years that is not restored for usage should be recovered gradually after being reported to and approved by the People's Government at the county level by famers collective. Finally, the standardization management of the right to use, registration and certification of the rural homestead should be strengthened so as to make the housing land use right registration system play its due efficiency and be the legal base for homestead management and so on.[3]

\section{B. Protect the legal rights of farmers' residential land}

Homestead is the fundamental for living in peace and one important property right of the farmers. In the process of carrying out the centralized residence, it is necessary to fully protect the farmers' right to use the homestead. In addition to the compensation for the farmers' property on the homestead, for the homestead itself, either provide the right to use the collective land or make adequate and timely compensation, which is the necessary prerequisite for the development of centralized residence work. The issues of farmers being unable to get collective land use permits who have moved into the centralized residential areas involves legal obstacles to the transfer of rural land. It is suggested that the state should improve relevant laws and regulations, endow the farmer's homestead with a complete real right, and regulate the transfer of the homestead into the market, breaking the restrictions on the transfer of the homestead only in the collective economic organization so as to ensure full liquidity of farmers' land and property rights.

\section{Improve public participation and enhance the credibility of planning}

Farmers should be the main body of homestead withdrawal. In the process of guiding farmers to withdraw from the homestead, local government should take the needs of farmers as the guide, take the interests of farmers into account, and fully respect the wishes of farmers. We must resolutely prevent the phenomenon of violating the wishes of farmers to reconstruct in large-scale and build high buildings blindly.

At present, the specific norms of farmers' participation in the process of village and town planning are not clear. Under such situation, our country should modify relevant laws and regulations as soon as possible and establish effective villagers' participation mechanism so that the construction of centralized residence is truly in line with the fundamental interests of farmers. In terms of specific norms, at least the following systems should be established: first, publicity system. The formulation basis, planning content and compensation scheme of the centralized residence plan should be published in a timely manner in the designated media and planning areas, and should widely consult opinions. In order to fully guarantee the farmers' right to know and participate, time limit for consultation should not be less than 30 days. The second is opinion feedback mechanism. For farmers' opinions and suggestions, we should give feedback in time and explain in detail. And the adjustment of planning should also be announced in time.[4]

\section{CONCLUSION}

From the current homestead management system and the practice of centralized residence, the amount of homestead compensation is relatively low and there is uncertainty for farmers' long-term living security and housing security after the withdrawal from homestead, which resulted in farmers' refusal or unwillingness to withdraw from the houses. Therefore, we must precede for the sake of social stability, narrow the gap between urban and rural areas and nurturing agriculture by industry. We should encourage shifting interests reasonably to farmers in the process of homestead withdrawal, and actively improve the rural social security mechanism as well as stripping social security function of homestead, so that to establish an objective and fair evaluation system for homestead and an economic compensation mechanism that ensures "the same land, the same rights and the same price" with state-owned land; based on the long-term livelihood of farmers and the local actual situation, establish a system for withdrawing from living houses for farmland or a system of concessions for buying houses etc. to encourage homestead withdrawal in various ways. Ensure farmers' basic life and quality of life after withdrawing from the homestead.

\section{REFERENCE}

[1] Cao Bantian, Study on the legal issues of the transfer of the right to use Homestead [M] Beijing: Law Publishing House, 2012:123-124.

[2] Mao Weiguo, Study on the circulation system of rural housing and homestead [J] Legal Forum, 2012(6):104.

[3] Wang Chongmin, Discussion on the change of the right to use the rural homestead in China [J] Journal of Henan University of Economics and Law, 2012(4):170.

[4]Zeng Jian, Research on the compensation and resettlement system of rural collective land acquisition under the background of urban rural integration [J] Eastern Jurisprudence, 2013.(4):56. 